\title{
Enantioselective total synthesis of bioactive natural product $(+)-S c h$ 642305: a structurally novel inhibitor of bacterial DNA primase and HIV-1 Tat transactivation $\dagger$
}

\author{
Goverdhan Mehta* and Harish M. Shinde
}

Received (in Cambridge, UK) 14th April 2005, Accepted 18th May 2005

First published as an Advance Article on the web 10th June 2005

DOI: $10.1039 / \mathrm{b505264e}$

The total synthesis of the bioactive natural product $(+)-S c h$ 642305 has been achieved from a readily available chiral building block using an RCM protocol to construct the key decalactone moiety; our approach is notable for its built-in flexibility and is diversity oriented.

Bacterial infections constitute a serious threat to human health worldwide due to the rapid emergence of antibiotic-resistant strains, underscoring the urgent need for the development of new classes of antibacterial agents. ${ }^{1}$ In this context, target and mechanism-based drug discovery methods, utilizing both natural products and synthetic libraries, are being explored in the search for alternative antibacterial therapeutics. Bacterial DNA primase (DnaG) is a DNA-dependent RNA polymerase that is crucial for the replication of bacterial chromosomal DNA. ${ }^{2}$ Genetic validation of DnaG indicated that the inhibition of bacterial primase causes a rapid bactericidal response. ${ }^{3}$ In the intricate process of DNA replication, DnaG has a pivotal role in initiating the ss RNA primer synthesis. It has been established that, while the replication of the leading-strand DNA requires only one RNA primer, that of the lagging strand DNA requires $>2000$ primer sites. Consequently, interruption of the RNA primer synthesis would eventuate in a catastrophic event in bacterial chromosome replication. Thus, DNA primase has emerged as a promising target for the discovery of new antibacterial drugs and its inhibition is an area of high priority pursuits. ${ }^{4,5}$

Towards the end of 2003, scientists at Schering-Plough reported the isolation and structure elucidation of a novel natural product, Sch 6423051 (Fig. 1), from the fermentation broth of the fungus

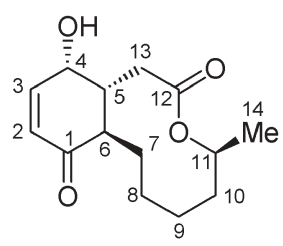

1

Fig. 1
Penicillium verrucosum (culture ILF-16214). ${ }^{4}$ The absolute configuration of $\mathbf{1}$ was determined through the anomalous diffraction effects in the X-ray crystallographic analysis of its $p$-bromobenzoate derivative. Besides its structural novelty, 1 exhibited inhibitory activity against Escherichia coli bacterial DNA primase enzyme with an $\mathrm{EC}_{50}$ value of $70 \mu \mathrm{M}$. It may also be pointed out that very few natural products exhibiting DnaG inhibition activity have been reported so far; with the notable exception of phenolic saccharides isolated recently from the Peruvian plant Polygonum cuspidatum sp..$^{5}$ In addition to its bacterial DNA primase inhibitory activity, a very recent report from a group at Merck indicates that Sch 642305 1, isolated this time from the fungus Septofusidium sp., exhibits inhibition of HIV-1 Tat-dependent transactivation with an $\mathrm{IC}_{50}$ value of $1.00 \mu \mathrm{M} .{ }^{6} \mathrm{HIV}-1$ Tat is one of the six regulatory proteins encoded by HIV and is essential for viral replication. ${ }^{7}$ Tat-protein therefore is an attractive target for the development of new therapeutics for the treatment of HIV infection. ${ }^{6}$

The varied range of potent biological activity shown by $\mathbf{1}$ justifies the development of synthetic routes to harness its potential, to serve as a platform for diversity generation and inhibitory activity modulation. From a purely structural perspective, the functionally-embellished bicyclic macrolide framework of 1, composed of a decalactone moiety fused to a 4-hydroxycyclohexenone ring, is new among natural products and the additional presence of four stereogenic centers makes it a challenging and
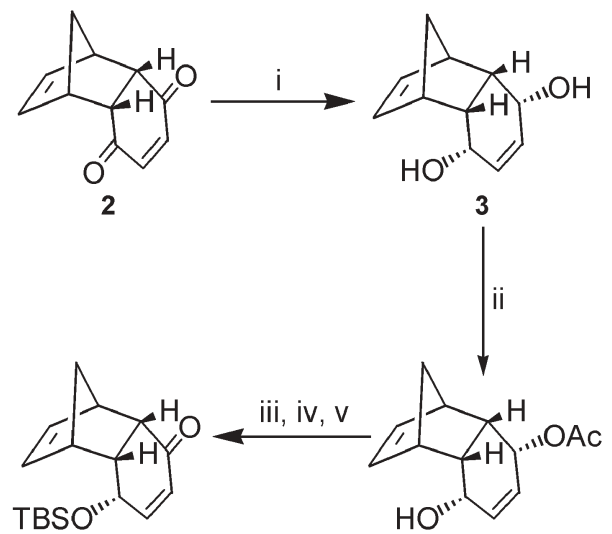

$(+)-5$

$(+)-4$

Scheme 1 Reagents and conditions: i, $\mathrm{NaBH}_{4}, \mathrm{CeCl}_{3}, \mathrm{MeOH}, 0{ }^{\circ} \mathrm{C}$, $15 \mathrm{~min}, 90 \%$; ii, lipase PS-D, vinyl acetate, THF, RT, 82\%; iii, TBSCl, imidazole, DMAP, DMF, 6 h, 94\%; iv, $\mathrm{K}_{2} \mathrm{CO}_{3}, \mathrm{MeOH}, 0{ }^{\circ} \mathrm{C}, 5 \mathrm{~h}$; v, PDC, $4 \AA$ AS, DCM, 1 h, $0{ }^{\circ} \mathrm{C}(90 \%$ for two steps). 


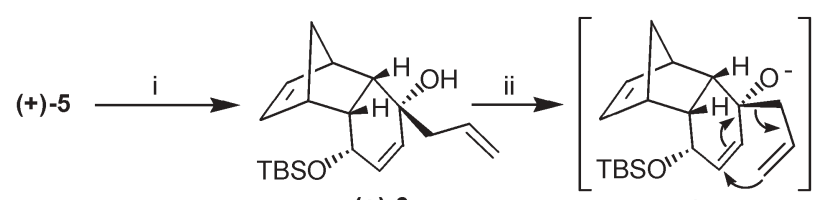

$(+)-6$

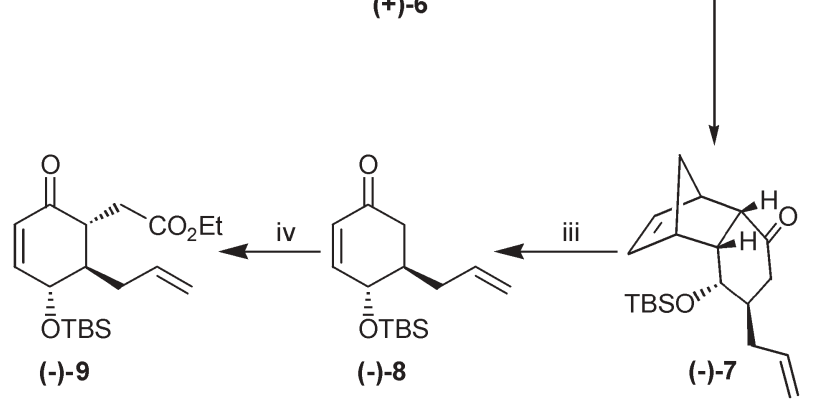

Scheme 2 Reagents and conditions: i, Zn, allyl bromide, sonication, THF, $10 \mathrm{~min}, 93 \%$; ii, $\mathrm{KH}$, dioxane, $85{ }^{\circ} \mathrm{C}, 30 \mathrm{~min}, 81 \%$; iii, diphenyl ether, $210{ }^{\circ} \mathrm{C}, 15 \mathrm{~min}, 85 \%$; iv, LDA, $\mathrm{BrCH}_{2} \mathrm{CO}_{2} \mathrm{Et}$, HMPA, THF, $-78{ }^{\circ} \mathrm{C}, 69 \%$.

attractive synthetic proposition. We report here a short, enantioselective total synthesis of Sch 642305 1, which deploys an RCM protocol to construct the key decalactone moiety.

Our synthesis of Sch 6423051 commenced from the readily accessible (and commercially available) endo-tricyclic Diels-Alder adduct $\mathbf{2}$ of cyclopentadiene and $p$-benzoquinone. Our initial objective was to render 2 chiral and chemo-differentiate the two carbonyl groups in the pendent cyclohexanoid ring. Stereoselective reduction of the carbonyl groups in $\mathbf{2}$ led to the meso,endo,endodiol 3 which, on lipase-mediated enzymatic desymmetrization, furnished enantiopure monoacetate $(+)-4$ ( 99\% ee) as described previously (Scheme 1). ${ }^{8}$ Further functional group transformations to $(+)-\mathbf{4}$ delivered the key building block $(+)-5$ quite conveniently.

Zinc-mediated Barbier-type allylation of $(+)-5$ proceeded smoothly and stereoselectively with exo-face selectivity, to deliver

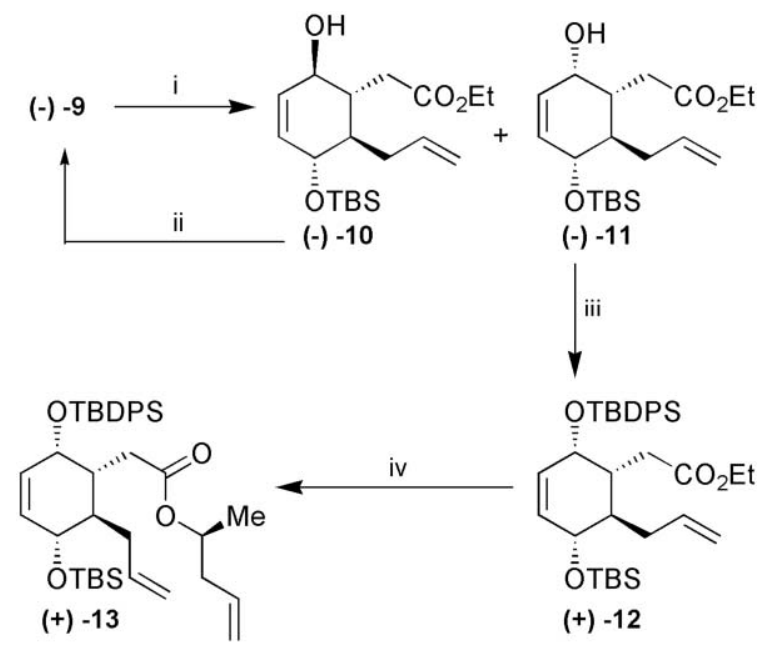

Scheme 3 Reagents and conditions: i, $\mathrm{NaBH}_{4}, \mathrm{CeCl}_{3}, \mathrm{MeOH},-50{ }^{\circ} \mathrm{C}$, $15 \mathrm{~min}, 80 \%, \alpha: \beta-\mathrm{OH}=1: 1.2$; ii, PDC, $4 \AA \mathrm{MS}, \mathrm{DCM}, 1 \mathrm{~h}, 0{ }^{\circ} \mathrm{C}, 92 \%$; iii, TBDPSCl, imidazole, DMAP, DMF, 93\%; iv, $(S)-(+)-4-$ pentene-2-ol, $\mathrm{Ti}\left(\mathrm{O}^{i} \mathrm{Pr}\right){ }_{4}, 90{ }^{\circ} \mathrm{C}, 91 \%$.

(+)-6 and set up the stage for an oxy-Cope rearrangement, Scheme 2. ${ }^{9}$ Anionic activation of (+)-6 led to the contemplated $[3,3]$ sigmatropic shift to provide the desired allylated product $(-)-7$ as a single diastereoisomer. ${ }^{9,10}$ At this juncture, the norbornyl scaffold was disengaged through a retro-Diels-Alder process to furnish the cyclohexenone (-)-8.9 ${ }^{9}$ Regio- and stereoselective alkylation of $(-)-8$ with ethyl bromoacetate led to (-)-9 with the requisite trans-disposition of the two side arms (Scheme 2). ${ }^{11}$

Luche reduction $^{12}$ of $(-)-9$ furnished a mixture $(1: 1.2)$ of diastereomeric alcohols (-)-10 and (-)-11, of which the latter had the requisite $\mathrm{C} 4$ stereochemistry of the natural product. ${ }^{9}$ However, the unwanted stereoisomer (-)-10 was also serviceable through recycling via PDC oxidation to (-)-9 (Scheme 3). The hydroxyl group in (-)-11 was protected as the TBDPS derivative (+)-12 and

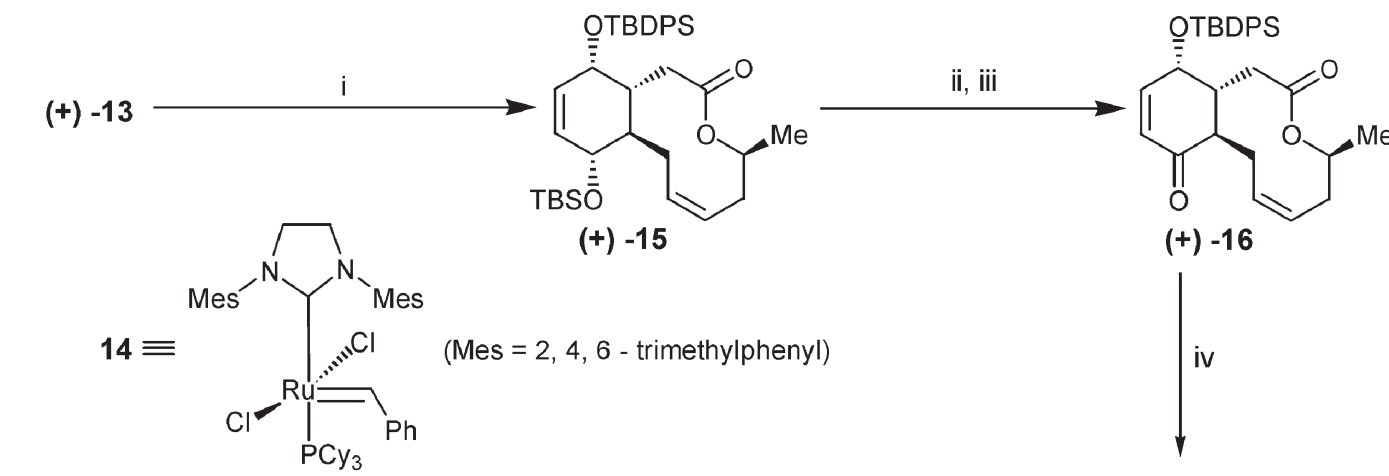

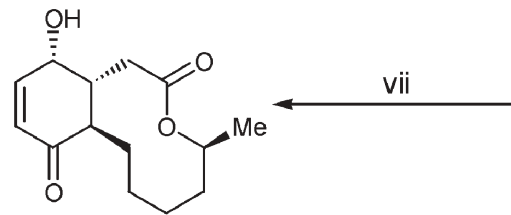

$(+)-1$<smiles>CC1CCCCC(CC(=O)OC(=O)O)C(O)C=CC1=O</smiles>

$(+)-18$

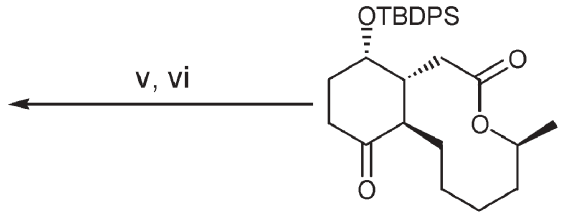

$(-)-17$

Scheme 4 Reagents and conditions: i, Grubbs II catalyst (14) (10 mol\%), DCM, reflux, 2 h, 84\%; ii, $\mathrm{PdCl}_{2}\left(\mathrm{CH}_{3} \mathrm{CN}\right)_{2}$, moist acetone, rt, 5 h, $94 \%$; iii, DessMartin periodinane, DCM, $0{ }^{\circ} \mathrm{C}, 6 \mathrm{~h}, 95 \%$; iv, $10 \% \mathrm{Pd} / \mathrm{C}, \mathrm{H}_{2}$, EtOAc, $96 \%$; v, LHMDS, PhSeCl, THF, $-78{ }^{\circ} \mathrm{C}$; vi, $\mathrm{H}_{2} \mathrm{O}_{2}$, pyridine, DCM, $0{ }^{\circ} \mathrm{C}, 10 \mathrm{~min}$ ( $78 \%$ for two steps); vii, TBAF-AcOH (1: 1), THF, RT, 8 h, 91\%. 
the ethyl ester moiety was subjected to transesterification with the matched $(S)$-4-pentene-2-ol to furnish $(+)-13$ (Scheme 3). ${ }^{9,13}$

In $(+)-13$, we had the precursor well poised for implementing the key RCM protocol. Indeed, exposure of $(+)-\mathbf{1 3}$ to the second generation Grubbs catalyst $\mathbf{1 4}^{14}$ resulted in the smooth generation of the bicyclic framework (+)-15 embodying the decalactone moiety (Scheme 4). At this stage, the logical endeavour was to selectively reduce the cyclodecene double bond but this proved to be quite difficult despite many variations in the catalyst and hydrogenation conditions. Consequently, an alternate strategy was devised. Pd(II)-mediated chemoselective TBS-deprotection ${ }^{15}$ of (+)-15 and subsequent oxidation of the generated hydroxyl functionality with Dess-Martin periodinane ${ }^{16}$ delivered the enone (+)-16. ${ }^{9}$ Catalytic hydrogenation of (+)-16 led to the fully saturated bicycle (-)-17 in which the enone double bond needed to be restored. $^{9}$ This was accomplished via a phenylselenationselenoxide elimination sequence. ${ }^{17}$ Thus, phenylselenation of (-)-17 was effected under kinetically controlled conditions to give an $\alpha$-phenylseleno compound which was directly oxidized with hydrogen peroxide to deliver the penultimate product $(+)-\mathbf{1 8}$ (Scheme 4). ${ }^{9}$ Finally, the TBDPS protection in (+)-18 was carefully removed with TBAF buffered with an equimolar amount of acetic acid, ${ }^{18}$ to furnish the target molecule Sch 642305 (+)-1. Our synthetic (+)-1 was found to be spectroscopically identical to the natural product (see ESI $\dagger$ ) and its $[\alpha]_{\mathrm{D}}+71.0^{\circ}\left(c, 0.31, \mathrm{CH}_{3} \mathrm{OH}\right)$ matched well with the reported values of $[\alpha]_{\mathrm{D}}+67.44^{\circ}(c, 0.50$, $\left.\mathrm{CH}_{3} \mathrm{OH}\right)$ for (+)-1. ${ }^{4}$

In summary, we have accomplished the first total synthesis of the bioactive natural product Sch $642305(+)-1$, through a concise, stereo- and enantioselective strategy which lends itself amenable to diversity creation for further exploring its therapeutic potential in the light of promising initial leads.

We thank Mr Atsuya Hirano and Mr Tan Nakagawa, Amano Enzyme Co., Nagoya, Japan for their generous gift of lipase PS-D. HMS, thanks CSIR, India for the award of a research fellowship. This research was supported by the Chemical Biology Unit of the JNCASR in Bangalore.

\section{Notes and references}

1 H. Richet, J. Mohammed, L. C. McDonald and W. R. Jarvis, Emerging Infect. Dis., 2001, 7, 319.

2 (a) J.-P. Bouché, K. Zechel and A. Kornberg, J. Biol. Chem., 1975, 250, 5995; (b) K.-I. Arai and A. Kornberg, Proc. Natl. Acad. Sci. U. S. A., 1979, 76, 4308

3 (a) M. Grompe, J. Versalovic, T. Koeuth and J. R. Lupski, J. Bacteriol., 1991, 173, 1268; (b) P. Shrimankar, L. Stordal and R. J. Maurer, J. Bacteriol., 1992, 174, 7689

4 M. Chu, R. Mierzwa, L. Xu, L. He, J. Terracciano, M. Patel, V. Gullo, T. Black, W. Zhao, T. Chan and A. T. McPhail, J. Nat. Prod., 2003, 66, 1527.

5 V. R. Hegde, H. Pu, M. Patel, T. Black, A. Soriano, W. Zhao, V. P. Gullo and T.-M. Chan, Bioorg. Med. Chem. Lett., 2004, 14, 2275.

6 H. Jayasuriya, D. L. Zink, J. D. Polishook, G. F. Bills, A. W. Dombrowski, O. Genilloud, F. F. Pelacz, L. Herranz, D. Quamina, R. B. Lingham, R. Danzeizem, P. L. Graham, J. E. Tomassini and S. B. Singh, Chem. Biodiversity, 2005, 2, 112.

7 S. K. Arya, C. Guo, S. F. Josephs and F. Wong-Staal, Science, 1985, 229, 69.

8 (a) S. Takano, Y. Higashi, T. Kamikubo, M. Moriya and K. Ogaswara, Synthesis, 1993, 948; (b) H. Konno and K. Ogaswara, Synthesis, 1999, 1135; (c) G. Mehta and K. Islam, Synlett, 2000, 1473.

9 All new compounds were fully characterized on the basis of their IR, ${ }^{1} \mathrm{H}-\mathrm{NMR},{ }^{13} \mathrm{C}-\mathrm{NMR}$, and HRMS data (see ESI $\dagger$ ).

10 For an anion-assisted sigmatropic rearrangements, see: S. R. Wilson, Org. React., 1993, 43, 93.

11 K. F. Podraza and R. L. Bassfield, J. Org. Chem., 1989, 54, 5919.

12 A. L. Gemal and J. L. Luche, J. Am. Chem. Soc., 1981, 103, 5454.

13 D. Seebach, E. Hungerbühler, R. Naef, P. Schnurrenberger, B. Weidmann and M. Züger, Synthesis, 1982, 138.

14 (a) M. Scholl, S. Ding, C. W. Lee and R. H. Grubbs, Org. Lett., 1999, 1, 953; (b) For recent reviews on RCM, see: (i) A. Fürstner, Angew. Chem., Int. Ed., 2000, 39, 3012; (ii) T. M. Trnka and R. H. Grubbs, Acc. Chem. Res., 2001, 34, 18.

15 (a) N. S. Wilson and B. A. Keay, J. Org. Chem., 1996, 61, 2918; (b) B. H. Lipshutz, D. Pollart, J. Monforte and H. Kotsuki, Tetrahedron Lett., 1985, 26, 705.

16 D. B. Dess and J. C. Martin, J. Org. Chem., 1983, 48, 4155.

17 H. J. Reich, J. M. Renga and I. L. Reich, J. Am. Chem. Soc., 1975, 97, 5434.

18 A. B. Smith, III and G. R. Ott, J. Am. Chem. Soc., 1996, 118, 13095. 